\title{
Organizational-Economic Trends and Urgent Problems of Digitalization of the Economy of the Republic of Kazakhstan
}

\author{
Ersultan Beisembai ${ }^{1 *}$, Alexey A. Titkov ${ }^{1}$, Saule I. Zhumagalievna ${ }^{2}$ \\ ${ }^{1}$ Toraighyrov University, 64 Lomova str., 64, 140000, Pavlodar, Kazakhstan \\ ${ }^{2}$ Kazakh University of Technology and Business, 37A K.Mukhamedkhanova str., \\ 010000, Nur-Sultan, Kazakhstan
}

\begin{abstract}
The purpose of this scientific article is to identify modern trends in the formation of the economic and organizational foundations for the development of the digital economy of the Republic of Kazakhstan, to identify the main problems in these areas and ways to solve them. The main initial data for writing a scientific article were official statistical information in the field of development of communications and information and telecommunication technologies, scientific periodicals, including the near and far abroad, practical data of entrepreneurial structures directly leading production and economic activities in the digital and computer technology. The hypothesis of scientific research is the need to form the institutional foundations for building a digital economy, focused on the implementation of infrastructural development of digitalization processes at the macro and micro levels. The institutional framework affects both the public sector and the business entrepreneurship sector. In the strategic period for the development of the digital economy, indicative programs for business structures, as well as organizational scenarios for the state, should be developed. The main methods of scientific research were analytical and synthetic, statistical, computational, and analytical research methods, the method of hypotheses. As the results of the study, attention was focused on the dynamics of the contribution of digitalization processes to the economic growth of the Republic of Kazakhstan, and the main economic problems that hinder the intensification of the development of the digital economy were identified. The main scientific contribution of the study is focused on the priorities for solving the problems of digitalization of the economy within the strategic and long-term periods, including micro- and macroeconomic levels.
\end{abstract}

Keywords: digital economy, digitalization organization, economic foundations, digital market, digitalization industries, digitalization efficiency.

For citation: Beisembai, E., Titkov, A.A. \& Ibraimov, S.Zh. (2021). Organizational-Economic Trends and Urgent Problems of Digitalization of the Economy of the Republic of Kazakhstan. Economics: the Strategy and Practice, 16(3), 51-67, https://doi.org/10.51176/1997-9967-2021-3-51-67

* Corresponding author: Ersultan Beisembai - PhD candidate of the Department of Economics, Toraighyrov University, 64 Lomova str., 140000, Pavlodar, Republic of Kazakhstan, +87714768824, e-mail: beisembai_ersultan@, mail.ru.

Conflict of interests: the authors declare that there is no conflict of interest.

Financial support: The study was carried out within the framework of extra-budgetary funding sources within the framework of $\mathrm{PhD}$ doctoral studies at Toraighyrov University with a degree in economics. In the course of research and writing a scientific article, advisory support was provided by leading scientists of the Department of Economics of Toraighyrov University.

The article received: 07.08 .2021

The article approved for publication: 16.08 .2021

Date of publication: 30.09 .2021 
INNOVATION, INNOVATION AND TECHNOLOGICAL DEVELOPMENT, DIGITALIZATION

\title{
Қазақстан Республикасының экономикасын цифрландырудын ұйымдық-экономикалық тенденциялары мен өзекті мәселелері
}

\author{
Бейсембай Е. ${ }^{*}$, Титков А.А. ${ }^{1}$, Ибраимова С.Ж. ${ }^{2}$ \\ ${ }^{1}$ Торайдыров университеті, Ломова к., 64, 140000, Павлодар к.., Қазақсстан \\ ${ }^{2}$ Қазақ Технологиялар және Бизнес Университеті, Қ.Мұхамедханова к., 37 А, \\ 010000, Нұр-Сұлтан, Қазақ̧стан
}

\begin{abstract}
Түйін
Бұл ғылыми мақаланың мақсаты - Қазақстан Республикасының цифрлық экономикасын дамытудың экономикалық және ұйымдастырушылық негіздерін қалыптастырудың заманауи тенденцияларын анықтау, осы салалардағы негізгі проблемалар мен оларды шешу жолдарын анықтау. Ғылыми мақала жазу үшін негізгі бастапқы деректер коммуникация мен ақпараттық және телекоммуникациялық технологияларды дамыту саласындағы ресми статистикалық ақпарат, ғылыми мерзімді басылымдар, оның ішінде алыс және жақын шетелдер, цифрлық жүйеде өндірістік -экономикалық қызметті тікелей жүргізетін кәсіпкерлік құрылымдардың практикалық деректері болды. және компьютерлік технология. Ғылыми зерттеулердің гипотезасы - бұл цифрландыру процестерінің инфрақұрылымдық дамуын макро және микродеңгейде жүзеге асыруға бағытталған цифрлық экономиканы құрудың институционалдық негіздерін қалыптастыру қажеттілігі. Институционалды құрылым мемлекеттік секторға да, кәсіпкерлік кәсіпкерлікке де әсер етеді. Цифрлық экономиканы дамытудың стратегиялық кезеңінде бизнес -құрылымдар үшін индикативті бағдарламалар, сондай -ақ жалпы мемлекет үшін ұйымдастырушылық сценарийлер әзірленуі тиіс. Ғылыми зерттеудің негізгі әдістері: аналитикалық және синтетикалық, статистикалық, есептік және аналитикалық зерттеу әдістері, гипотезалар әдісі болды. Зерттеу нәтижелері ретінде цифрландыру үдерістерінің Қазақстан Республикасының экономикалық өсуіне қосатын үлесінің динамикасына назар аударылды және цифрлық экономиканың қарқынды дамуын тежейтін негізгі экономикалық проблемалар анықталды. Зерттеудің негізгі ғылыми үлесі микро- және макроэкономикалық деңгейлерді қоса алғанда, стратегиялық және ұзақ мерзімді кезеңдерде экономиканы цифрландыру мәселелерін шешудің басымдық- тарына бағытталған.
\end{abstract}

Түйін сөздер: цифрлық экономика, цифрландыруды ұйымдастыру, экономикалық негіздер, цифрлық нарық, цифрландыру индустриялары, цифрландырудың тиімділігі.

Дәйексөз алу үшін: Бейсембай Е., Титков А.А., Ибраимова С.Ж. (2021). Қазақстан Республикасының экономикасын цифрландырудың ұйымдық-экономикалық тенденциялары мен өзекті мәселелері. Экономика: стратегия және практика, 16(3), 51-67, https://doi.org/10.51176/1997-9967-2021-3-51-67

* Хат-хабаршы авторы: Бейсембай Ерсұлтан - Торайғыров университеті, $\mathrm{PhD}$ кандидаты, экономика кафедрасының, Ломова к., 64, 140000, Павлодар қ., Қазақстан Республикасы, +87714768824, e-mail: beisembai_ersultan@mail.ru.

Мүдделер қақтығысы: авторлар мүдделер қақтығысының жоқтығын мәлімдейді.

Қаржыландыру. Зерттеу Экономика мамандығы бойынша университеттің $\mathrm{PhD}$ докторантурасында оку шеңберінде бюджеттен тыс қаржыландыру көздері шеңберінде жүргізілді.

Зерттеу және ғылыми мақала жазу барысында университеттің Экономика кафедрасының жетекші ғалымдары тарапынан консультативтік қолдау көрсетілді.

Мақала редакцияға түсті: 07.08.2021

Жариялау туралы шешім қабылданды: 16.08 .2021

Жарияланды: 30.09.2021 


\title{
Организационно-экономические тенденции и актуальные проблемы цифровизации экономики Республики Казахстан
}

\author{
Бейсембай Е. ${ }^{*}$, Титков А.А. ${ }^{1}$, Ибраимова С.Ж. ${ }^{2}$ \\ ${ }^{1}$ Павлодарский государственный университет им. С. Торайгырова, ул.Ломова, 64, \\ 140000, Павлодар қ., Қазақсстан \\ ${ }^{2}$ Казахский университет технологии и бизнеса, ул. К. Мухамедханова, 37 А, \\ 010000, Нур-Султан, Казахстан
}

\begin{abstract}
Аннотация
Цель настоящей научной статьи - обозначить современные тенденции формирования экономических и организационных основ развития цифровой экономики Республики Казахстан, выявить основные проблемы в данных областях и пути их решения. Основными исходными данными для написания научной статьи послужили официальная статистическая информация в области развития связи и информационнотелекоммуникационных технологий, научно- периодические журналы, в том числе ближнего и дальнего зарубежья, были использованы практические данные предпринимательских структур непосредственно ведущих производственно-хозяйственную деятельность на рынке цифровых и компьютерных технологий. Гипотеза научного исследования заключается в необходимости формирования институциональных основ построения цифровой экономики, ориентированных на реализацию инфраструктурного развития процессов цифровизации на макро- и микроуровнях. Институциональные основы затрагивают как государственный сектор, так и сектор бизнес-предпринимательства. В стратегическом периоде для развития цифровой экономики должны быть разработаны индикативные программы для предпринимательских структур, а также организационные сценарии для государства в целом. Основными методами научного исследования выступали: аналитический и синтетический, статистический, расчетно-аналитический методы исследования, метод гипотез. В качестве результатов исследования было акцентировано внимание на динамику вклада процессов цифровизации в экономический рост Республики Казахстан, а также были обозначены основные экономические проблемы, препятствующие интенсификации развития цифровой экономики. Основной научный вклад исследования сосредоточен на приоритетах решения проблем цифровизации экономики в рамках стратегического и долгосрочного периодов включая микро- и макроэкономические уровни.
\end{abstract}

Ключевые слова: цифровая экономика, организация цифровизации, экономические основы, цифровой рынок, отрасли цифровизации, эффективность цифровизации.

Для цитирования: Бейсембай Е., Титков А.А., Ибраимова С.Ж. (2021). Организационно-экономические тенденции и актуальные проблемы цифровизации экономики Республики Казахстан. Экономика: стратегия и практика, 16(3), 51-67, https://doi.org/10.51176/1997-9967-2021-3-51-67

* Корреспондирующий автор: Бейсембай Ерсултан - Торайгыров университет, докторант $\mathrm{PhD}$ кафедры Экономики, ул. Ломова 64, 140000, г. Павлодар, Республика Казахстан, +87714768824, e-mail: beisembai ersultan@mail.ru.

Конфликт интересов: авторы заявляют об отсутствии конфликта интересов.

Финансирование. Исследование проведено в рамках внебюджетных источников финансирования в рамках обучения в $\mathrm{PhD}$ докторантуре Торайгыров университета по специальности экономики. В ходе исследования и написания научной статьи консультативная поддержка была оказана со стороны ведущих ученых кафедры экономики Торайгыров университета.

Статья поступила в редакцию: 07.08 .2021

Принято решение о публикации: 16.08 .2021

Опубликовано: 30.09 .2021 


\section{Введение}

В условиях нарастающих тенденций четвертой научно-технической революции, в глобальной мировой экономике имеют место активные процессы перехода экономических систем на уровень нового качества - цифровой экономики. Данный вид экономики основан на интернет-технологиях, электронном бизнесе и электронной коммерции, электронной автоматизации производственно-хозяйственных процессов в системе функционирования предприятий и отраслей экономики.

С учетом тесной интеграции Республики Казахстан в глобальные экономические процессы актуально построение и развитие цифровой экономики на национальном, отраслевом и межотраслевом уровнях.

Цель настоящей научной статьи проанализировать современные тенденции формирования экономических и организационных основ развития цифровой экономики Республики Казахстан, выявить основные проблемы в данных областях и пути их решения. Это позволяет выработать основные гипотезы ускорения трансформации экономики от традиционного типа к экономике, основанной на цифровых технологиях.

Для построения и развития цифровой экономики в Республике Казахстан на государственном уровне разработаны и приняты специальные целевые стратегические программы - «Информационный Казахстан - 2020», «Цифровой Казахстан». Данные программы находятся на этапе первичной реализации и прорабатываются вопросы механизмов их эффективной реализации.

$\mathrm{B}$ целях обоснования путей, гипотез развития цифровой экономики в Республике Казахстан, требуется углубленный анализ и оценка влияния цифровизации экономики на все аспекты производственно-экономических и социально-экономических подсистем с последовательной выработкой механизмов трансформации от традиционной экономики к экономике, основанной на комплексном применении цифровых технологий. В перспективе, поступательное развитие цифровой экономики, рынков цифровой продукции и услуг, интернет-вещей должно интенсивно способствовать повышению уровня инновационности и конкурентоспособности Республики Казахстан, значительному повышению качества жизни населения, вхождению промышленных предприятий в систему мирового разделения труда.

\section{Литературный обзор}

Цифровая экономика в современных моделях деятельности различных стран мира рассматривается как новый этап эволюции производственно-хозяйственной деятельности и социальной деятельности общества. Цифровая экономика в полной мере соответствует мировым трендам «Четвертой промышленной революции» (Индустрия 4.0).

Согласно общепринятым энциклопедическим данным, цифровая экономика - это процесс функционирования экономической системы, основанный на комплексном применении компьютерной техники, программного обеспечения, цифровой связи и сетевых коммуникаций [1].

Первоначальный научный подход $\mathrm{\kappa}$ пониманию сущности цифровой экономики был предложен американским ученым информатиком-программистом Николасом Негропонте. В качестве основных постулатов инновационной экономики были определены: минимизация материального физического состояния товаров и услуг (минимизация веса, сырья и материалов); минимизация важности сырь и материалов при производственном процессе; создание нематериальных или частично-материальных товаров с элементами виртуальной реальности; мгновенное перемещение товаров и услуг от производителя к потребителю [2].

Следует отметить, что в современном научном сообществе, прослеживается тенденция, что как такового, четко определенного понятия «цифровая экономика» не существует, а имеющие место детерминанты носят многофакторный характер.

Кандидат экономических наук, доцент Московского государственного университета им. М.В. Ломоносова Энговатова А. формулирует научную гипотезу о том, что цифровая экономика представляет совокупность кардинально новых методов аккумулирования информационных данных, в процессе использования которых претерпевают изменения все стороны бизнес-процессов хозяйствующих субъектов [3].

Доцент Омского государственного технического университета Калужский М.Л., рассматривает цифровую экономику как коммуникационную среду, связанную с глобальной сетью Интернет, которая располагает инструментарием ее эффективного и целенаправленного использования [4].

В своем роде, уникальной точки зрения относительно понимания цифровой экономики придерживается американский ученый, футуролог, специалист в области 


\section{ИННОВАЦИИ, ИННОВАЦИОННО-ТЕХНОЛОГИЧЕСКОЕ РАЗВИТИЕ, ЦИФРОВИЗАЦИЯ}

кибернетики Келли К., который сопоставляет цифровую экономику с совокупностью все коммуникаций, которые выступают ядром, центром притяжения всех других элементов цифровой экономики $[5,6]$.

Большинство ученых в качестве сущности цифровой экономики рассматривают науку об удовлетворении потребности всех ее субъектов, связанной с использованием цифровой информации и соответствующей цифровой инфраструктуры $[7,8]$.

В научных трудах ученых, посвященных вопросам цифровой экономики, отдельные научные взгляды посвящены вопросам формирования организационных и экономических основ цифровизации. Так, в научной статье Litvinenko V.S. отмечается, что цифровая экономика нуждается в интеграции с научнопроизводственными структурами, научными центрами, при этом должна быть сформирована определенная система подготовки кадров [9]. Ученые Nosova S.S., Makar S.V., Gerasimenko T.I., Medvedeva O.E., Abdulov R.E. акцентируют внимание, что для построения и развития цифровой экономики должны быть проработаны возможные вариативные бизнесмодели [10]. Ряд других ученых из дальнего зарубежья полагают, что цифровая экономика c организационной точки зрения, должна пройти три этапа: оцифровка, цифровизация и цифровая трансформация. В процессе цифровизации должен быть задействован максимальный инвестиционный потенциал $[11,12]$.

По нашему мнению, цифровая экономика - это сложное и многогранное явление, непосредственно связанное с динамичным и расширенным созданием материальных благ c использованием цифровых технологий, нематериальных благ в цифровом формате и оказывающее значительное влияние на организационно-экономические процессы в сфере материального производства, социальноэкономические процессы в жизни как отдельного человека, так и общества в целом [13].

Построение цифровой экономики, как и любых других экономических систем обуславливается наличием организационных и экономических основ. Учеными современниками для организационных и экономических основ цифровизации вырабатываются соответствующие структурные элементы, критерии [14, 15].
В качестве базовых организационных основ построения и развития цифровой экономики выступают организация поставок цифрового оборудования, цифровых товаров; появление (создание) торговых предприятий по продаже цифрового оборудования, цифровых товаров и услуг; появление (создание) производственных предприятий (производство цифрового оборудования, цифровых товаров и услуг); формирование инфраструктурных основ цифровизации (цифровая связь, цифровые коммуникации); создание основ государственного регулирования и содействия развитию цифровой экономики. Экономическими основами развития цифровой экономики являются формирование предложения цифрового оборудования, цифровых товаров; формирование предложения цифровых услуг, цифровой информации; производство цифрового оборудования, цифровых товаров, услуг; формирование спроса на цифровое оборудование, цифровые товары и услуги.

Тенденции формирования предложения и спроса на цифровое оборудование, товары и услуги создают основы зарождения первичного цифрового рынка, который способствует занятости населения в первичных отраслях цифровой экономики и динамичному росту потребностей во всех видах цифровой продукции. Под воздействием факторов научно-технического прогресса происходит мультипликативный рост данных потребностей.

В формировании экономических основ построения и развития цифровой экономики значительную роль играют развитие международной торговли, интеграция национальной экономики в систему международной торговли (рисунок 1).

Организационные и экономические основы построения и развития цифровой экономики носят динамичный характер, происходит их трансформационное изменение под влиянием рыночной среды, политики государственного регулирования. 


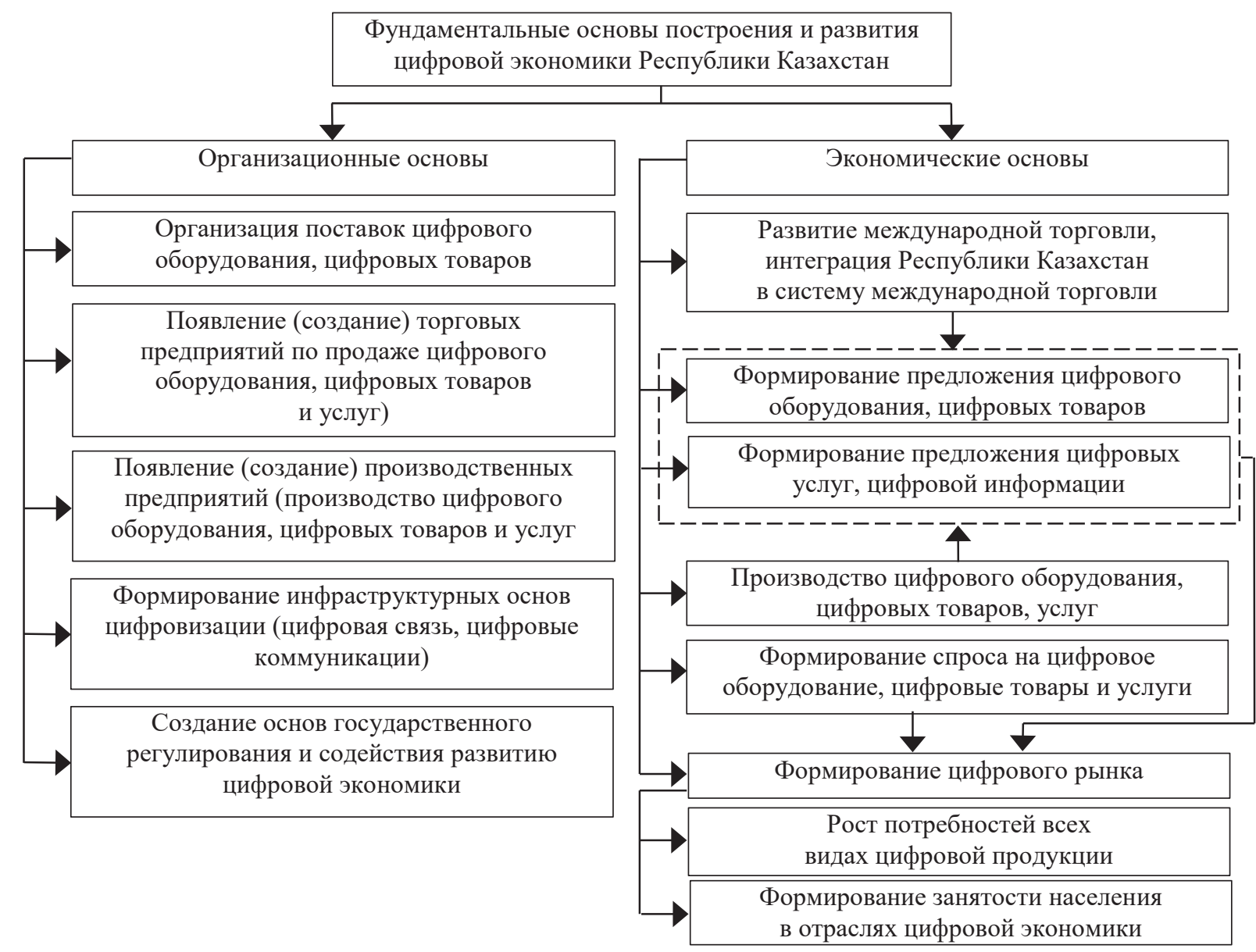

Рисунок 1 - Систематизация экономических и организационных основ построения и развития цифровой экономики Республики Казахстан

Figure 1 - Systematization of the economic and organizational foundations for the construction and development of the digital economy of the Republic of Kazakhstan

Примечание - Составлено авторами.

\section{Методология}

Проведение научного исследования основывалось на применении классической научной методологии. В качестве основных методов исследования выступали: аналитический и синтетический, статистический, расчетно-аналитический методы исследования. Также был использован метод проектирования гипотез. Алгоритм научных исследований основывался на аналитическом методе исследования, в рамках которого были проанализированы в отдельности все составные элементы экономических и организационных основ Республики Казахстан. Аналитический метод позволил определить проблемные организационные и экономические точки функционирования цифровой экономики. Второй этап алгоритма исследования был сопряжен со статистическим методом и расчетно-аналитическим методом при конкретизации отдельных индикативных показателей. На третьем этапе исследования был применен синтетический метод и метод гипотез. В рамках основной гипотезы было определено, что для ускорения развития цифровой экономики имеет место необходимость формирования институциональных основ построения цифровой экономики, ориентированных на реализацию инфраструктурного развития процессов цифровизации на макро- и микроуровнях. Информационной базой статьи послужили официальная статистическая информация в области развития связи и информационнотелекоммуникационных технологий, научнопериодические журналы, в том числе ближнего и дальнего зарубежья. 


\section{ИННОВАЦИИ, ИННОВАЦИОННО-ТЕХНОЛОГИЧЕСКОЕ РАЗВИТИЕ, ЦИФРОВИЗАЦИЯ}

\section{Результаты и обсуждение}

Построение и развитие цифровой экономики Республики Казахстан имело место параллельно глобальным, мировым тенденциям эволюции цифровизации экономических систем.

В период становления и развития рыночных отношений в Республике Казахстан, начиная с 1993 года, формирование предложения цифрового оборудования, цифровых товаров, а также цифровых услуг, цифровой информации, имело место за счет импортных поставок из стран дальнего и ближнего зарубежья (Российская Федерация). Первыми представителями цифровой продукции являлись все виды компьютерной техники.
В период начала рыночных реформ предложение на цифровом рынке Республики Казахстан было представлено компьютерами, компьютерным периферийным оборудованием, компьютерной оргтехникой; программным обеспечением многоцелевого назначения.

В период углубления рыночных реформ, по состоянию на 2001 год, объем рынка компьютеров составлял 101254,5 единиц, а ежегодное увеличение рынка имело тренд в объеме 11,6\%. Ежегодный объем продаж компьютеров, по состоянию на 2019 год был доведен до 300000 компьютеров (рисунок 2). Данный факт свидетельствовал о поступательном расширении и развитии рынка компьютерной техники.

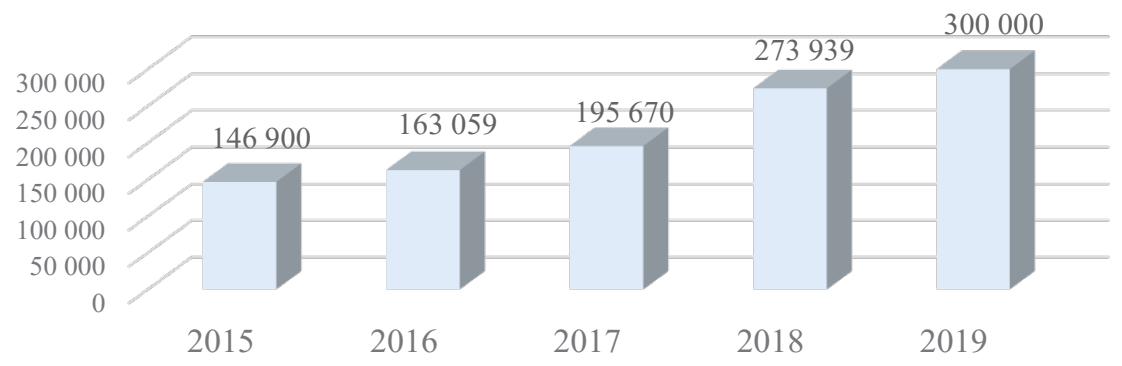

Рисунок 2 - Динамика продаж компьютеров на рынке в Республике Казахстан кол-во ед.

Figure 1 - Dynamics of sales of computers on the market in the Republic of Kazakhstan, number of units

Примечание - Составлено авторами по источнику [16].

На всех этапах рыночных реформ формирование цифрового рынка в Республике Казахстан находилось и находится в прямой зависимости от импорта компьютерной техники.
Максимальные объемы импорта компьютеров и сопутствующего оборудования приходились до 2015 года. В 2016 - 2019 годы наметились тенденции роста импорта компьютеров и компьютерного оборудования (таблица 1).

Таблица 1 - Динамика импорта компьютеров и компьютерного оборудования в сборе в Республику Казахстан.

Table 1 - Dynamics of import of computers and computer equipment assembled to the Republic of Kazakhstan

\begin{tabular}{|l|c|c|c|c|c|}
\hline \multicolumn{1}{|c|}{ Показатель } & \multicolumn{5}{c|}{ Год } \\
\cline { 2 - 7 } & 2015 & 2016 & 2017 & 2018 & 2019 \\
\hline $\begin{array}{l}\text { Импорт компьютеров и сопутствующего } \\
\text { оборудования, млн. долл. }\end{array}$ & 403 & 224,4 & 249,5 & 285,9 & 319,6 \\
\hline Темп роста импорта, \% & 64,3 & 55,7 & 111,2 & 114,6 & 111,8 \\
\hline
\end{tabular}

Примечание - Составлено по источнику [16]. 


\section{INNOVATION, INNOVATION AND TECHNOLOGICAL DEVELOPMENT, DIGITALIZATION}

Положительная динамика импорта компьютеров в рассматриваемый период была обусловлена расширением границ международного сотрудничества и международной торговли. Импорт компьютерной техники приходится на ведущие страны по производству электроники: Китай, Тайвань, Малайзия, Сингапур. Начиная с 2016 года, объем импортных поставок компьютеров сократился за счет девальвации национальной валюты и значительным ростом цен на импортируемую технику. Как показывает динамика импорта компьютеров, имела место цикличность их приобретения конечными потребителями.

По нашему мнению, цикличность спроса на компьютеры будет иметь место на системной основе, так как имеет место моральный износ компьютерной техники. В Республике Казахстан допустимый ежегодный уровень амортизации компьютерного оборудования, включая программное обеспечение составляет $40 \%$, что в свою очередь определяет минимально-допустимый его срок службы в 2,5 года.

В Республике Казахстан для обновления и удовлетворения спроса на компьютерную технику созданы и эволюционируют необходимые организационные основы. Функционирует широкая сеть торговых операторов, таких как Технодом, Белый Ветер, Alser, Sulpak, Fora.
Тренды морального устаревания компьютеров и сопутствующего компьютерного оборудования будут содействовать актуальности его обновления через каждые 2,5 - 3 года.

Наравне с тенденциями импорта, в Республике Казахстан формировались собственные производственные мощности по производству компьютеров. Следует отметить, что начиная с 1990 года по настоящее время, производство компьютеров не сопровождается полным производственным циклом, а сосредоточено на сборочных процессах из импортируемых комплектующих и периферийного оборудования. Производство отдельных комплектующих, применяемых при производстве компьютеров представлено в минимальном объеме.

Динамика производства компьютеров и сопутствующего компьютерного оборудования в Республику Казахстан, имеет циклический характер, но в комплексе характеризуется положительными трендами. Максимальные объемы производства компьютерного оборудования приходились на 2015 и 2019 годы. Максимальный объем производства электронных элементов и компьютерных системных плат имел место в 2015 году и составлял более $50 \%$ от общего объема производства компьютерного оборудования (таблица 2).

Таблица 2 - Динамика производства компьютеров и сопутствующего компьютерного оборудования в Республику Казахстан, млн. тенге.

Table 2 - Dynamics of production of computers and related computer equipment in the Republic of Kazakhstan, million tenge

\begin{tabular}{|l|c|c|c|c|c|c|}
\hline \multicolumn{2}{|c|}{ Показатель } & \multicolumn{5}{c|}{ Год } \\
\cline { 3 - 7 } & 2015 & 2016 & 2017 & 2018 & 2019 \\
\hline $\begin{array}{l}\text { Производство компьютеров и периферийного } \\
\text { оборудования }\end{array}$ & 4327,6 & 3210,9 & 2807,3 & 3638,3 & 5537,1 \\
\hline $\begin{array}{l}\text { Производство электронных элементов и } \\
\text { компьютерных системных плат }\end{array}$ & 2226,2 & 159,8 & 124,7 & 11,3 & 426,9 \\
\hline Итого & 6553,80 & 3370,70 & 2932,00 & 3649,60 & 5964,00 \\
\hline
\end{tabular}

Примечание - Источник [16].

На казахстанском цифровом рынке ведут производственно-коммерческую деятельность как старейшие предприятия по производству компьютеров и компьютерного оборудования, так и новые. Так, например, одними из старейших предприятий по производству компьютеров выступают ТОО «Фирма» КИП и $\mathrm{AO}$ «Логиком». Данные предприятия ведут свою деятельность с 1990 и 1992 годов соответственно. Среди всех предприятий по производственным мощностям лидирует АО «Логиком». Производственные мощности данного предприятия оцениваются в 900 тыс. персональных компьютеров в год с достигнут уровнем чистого казахстанского производства комплектующих в $25 \%$.

В 2020 году в Казахстане на базе производственных мощностей АО «Завод имени C.М. Кирова» в городе Петропавловске было запущено новое производство по выпуску 
компьютерной техники под брендом « $\mathrm{ZiK}$ computers». С учетом данного проекта, доля казахстанских компьютеров, в общем объеме продаваемой компьютерной техники была доведена до 30\% (рисунок 3).

Формирование предложения компьютеров и сопутствующего компьютерного оборудования повлияло на формирование спроса на компьютерную технику со стороны потенциальных потребителей. На современном этапе пользователями компьютеров выступает 82,2\% всех граждан в возрасте от 6 до 74 лет, при этом в возрасте от 6 до 15 лет компьютерами пользуется уже 80,8\% населения, что, по нашему мнению, является высоким показателем (таблица 3).

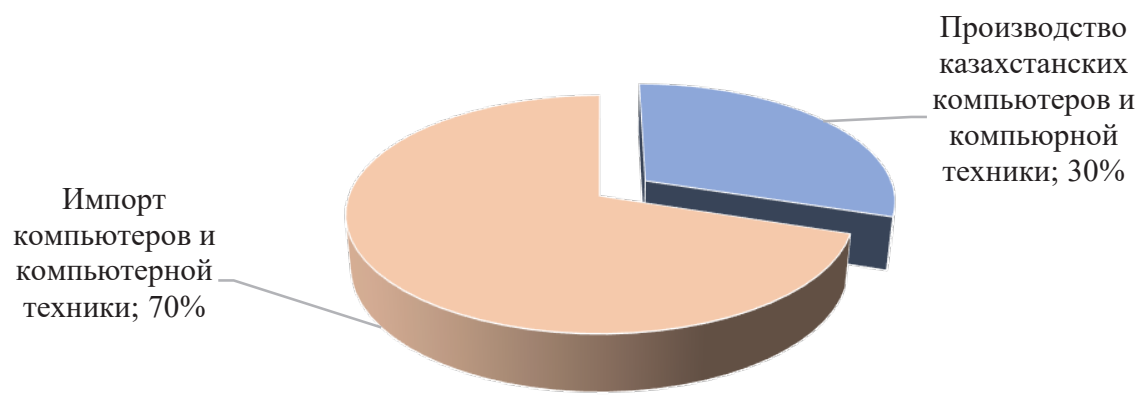

Рисунок 3 - Структура предложения компьютеров и компьютерной техники в разрезе компьютеров казахстанского производства и импортируемых из-за рубежа, 2020 год

Figure 3 - Structure of the supply of computers and computer equipment in the context of computers produced in Kazakhstan and imported from abroad, 2020

Примечание - Составлено автором.

Таблица 3 - Динамика удельного веса пользователей компьютеров (физических лиц) в Республике Казахстан, \%.

Table 3 - Dynamics of the share of computer users (individuals) in the Republic of Kazakhstan, \%

\begin{tabular}{|l|c|c|c|c|c|}
\hline \multicolumn{1}{|c|}{ Показатель } & \multicolumn{3}{c|}{ Год } \\
\cline { 2 - 7 } & 2015 & 2016 & 2017 & 2018 & 2019 \\
\hline $\begin{array}{l}\text { Пользователи компьютеров в возрасте от 6 до 74 лет, } \\
\text { в том числе: }\end{array}$ & 74,2 & 76,2 & 78,2 & 80,3 & 82,2 \\
\hline - пользователи компьютеров в возрасте от 6 до 15 лет & 60,5 & 65,3 & 73,8 & 76,9 & 80,8 \\
\hline - пользователи компьютеров в возрасте от 16 до 74 лет & 77,2 & 78,7 & 79,3 & 81,2 & 82,5 \\
\hline
\end{tabular}

Примечание - Источник [16].

На современном этапе и в ближайшем будущем уровень пользовательской активности компьютерами со стороны населения будет расти под воздействием развития рынка и процессов научно-технического прогресса.

Несмотря на высокий уровень приобретения пользовательских навыков работы на компьютерах, процент обеспеченности населения компьютерами остается не на высоком уровне. С 2015 по 2019 годы средний уровень обеспеченности домашних хозяйств вырос с $36,4 \%$ до 48,3\%. По состоянию на 2019 год максимальный уровень обеспеченности домашних хозяйств компьютерами имеет место по следующим их видам: настольные компьютеры - 54,2\%, ноутбуки - 55\%. В минимальной степени домашние хозяйства обеспечены планшетными компьютерами - 35,8\% (таблица 4). 


\section{INNOVATION, INNOVATION AND TECHNOLOGICAL DEVELOPMENT, DIGITALIZATION}

Таблица 4 - Динамика обеспеченности компьютерами домашних хозяйств в Республике Казахстан, \%

Table 4 - Dynamics of household computers supply in the Republic of Kazakhstan, \%

\begin{tabular}{|l|c|c|c|c|c|}
\hline \multicolumn{2}{|c|}{ Показатель } & \multicolumn{5}{c|}{ Год } \\
\cline { 2 - 7 } & 2015 & 2016 & 2017 & 2018 & 2019 \\
\hline $\begin{array}{l}\text { Средний уровень обеспеченности компьютерами } \\
\text { домашних хозяйства, в том числе: }\end{array}$ & 36,4 & 44,9 & 45,3 & 46,4 & 48,3 \\
\hline - настольные компьютеры & 54,1 & 58,0 & 55,2 & 54,3 & 54,2 \\
\hline - ноутбуки & 33,2 & 44,7 & 48,4 & 51,1 & 55,0 \\
\hline - планшетные компьютеры & 22,0 & 32,1 & 32,2 & 33,8 & 35,8 \\
\hline
\end{tabular}

Примечание - Источник [16].

В Республике Казахстан наблюдается количественный рост парка компьютерной техники во всех видах организаций. С 2015 по 2019 годы, рост парка компьютерной техники вырос незначительно с 935,3 тыс. ед. до 1108,4 тыс. ед. При этом максимальный темп роста парка компьютерной техники приходился на 2015 год (таблица 5).
В среднем, по состоянию на 2019 год, на одну организацию в Казахстане приходится около двух компьютеров, что является низким показателем (таблица 6).

Таблица 5 - Динамика количества компьютеров в организациях Республики Казахстан

Table 5 - Dynamics of the number of computers in organizations of the Republic of Kazakhstan

\begin{tabular}{|l|c|c|c|c|c|}
\hline \multicolumn{1}{|c|}{ Показатель } & \multicolumn{5}{c|}{ Год } \\
\cline { 2 - 7 } & 2015 & 2016 & 2017 & 2018 & 2019 \\
\hline $\begin{array}{l}\text { Общее количество компьютеров в организациях } \\
\text { Республики Казахстан, тыс. ед. }\end{array}$ & 935,3 & 951,8 & 977,2 & 1042,8 & 1124,1 \\
\hline Темп роста количества компьютеров, \% & 106,0 & 101,8 & 102,7 & 106,7 & 107,8 \\
\hline
\end{tabular}

Примечание - Источник [16].

Таблица 6 - Оценка динамики уровня обеспеченности организаций Республики Казахстан компьютерами

Table 6 - Assessment of the dynamics of the level of provision of organizations of the Republic of Kazakhstan with computers

\begin{tabular}{|l|c|c|c|c|c|}
\hline \multicolumn{1}{|c|}{ Показатель } & \multicolumn{5}{c|}{ Год } \\
\cline { 2 - 6 } & 2015 & 2016 & 2017 & 2018 & 2019 \\
\hline $\begin{array}{l}\text { Общее количество компьютеров в организациях } \\
\text { Республики Казахстан, тыс. ед. }\end{array}$ & 935,3 & 951,8 & 977,2 & 1042,8 & 1124,1 \\
\hline $\begin{array}{l}\text { Количество организаций в Республике Казахстан, } \\
\text { тыс. ед. }\end{array}$ & 360,3 & 383,9 & 412,7 & 433,8 & 446,7 \\
\hline $\begin{array}{l}\text { Уровень обеспеченности организаций Республики } \\
\text { Казахстан компьютерами, тыс. ед./организацию }\end{array}$ & 3 & 2 & 2 & 2 & 3 \\
\hline
\end{tabular}

Примечание - Составлено авторами по источникам $[16,17,18,19]$.

Невысокий уровень обеспеченности компьютерной техникой казахстанских организаций, по нашему мнению, связан с такими факторами, как:

- высокий уровень инфляционных процессов и постоянное удорожание компьютерной техники за счет прямых импортных поставок компьютеров и комплектующих;
- высокие темпы морального износа компьютерной техники;

- недостаточные резервы прибыли предприятий, фирм, компаний для систематических инвестиций в обновление парка компьютерной техники.

Углубление экономических и организационных основ построения и развития цифровой экономики, наравне с импортом и 


\section{ИННОВАЦИИ, ИННОВАЦИОННО-ТЕХНОЛОГИЧЕСКОЕ РАЗВИТИЕ, ЦИФРОВИЗАЦИЯ}

производством компьютерной техники, имело место по следующим направлениям:

- появление и развитие в стране Интернета;

- создание необходимых инфраструктурных основ цифровой связи;

- производство и продажа программного обеспечения многоцелевого назначения, оказание дополнительных услуг;

- развитие интернет-коммерции;

- цифровизация деятельности государственных и частных организаций;

- зарождение рынка интернет-вещей.
По состоянию на 2020 год координация казахстанским интернетом осуществляется Министерством цифрового развития, инноваций и аэрокосмической промышленности Республики Казахстан. Первичным ведущим провайдером глобальной сети Интернет в Республике Казахстан, выступает национальная Компания АО «Қазақтелеком».

В Республике Казахстан интернет пользуется широким спросом как со стороны физических, так и юридических лиц. С 2015 по 2019 годы, объем оказанных услуг по доступу к сети Интернет вырос со 190,4 млрд. тенге до 282,3 млрд. тенге (рисунок 4).

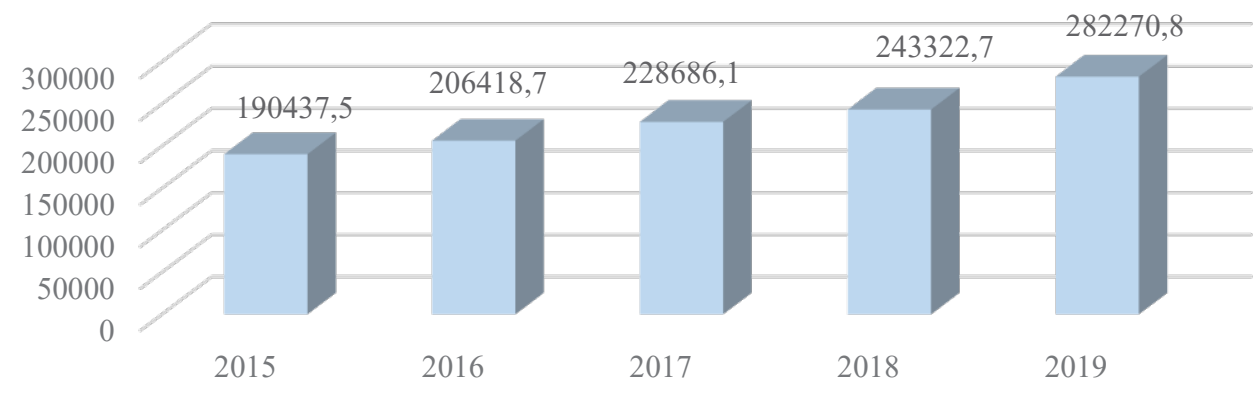

Рисунок 4 - Динамика оказания услуг по доступу к сети интернет в Республике Казахстан, млн. тенге

Figure 4 - Dynamics of the provision of services for access to the Internet in the Republic of Kazakhstan, million tenge

Примечание - Источник [16].

Уровень обеспеченности интернетом домашних хозяйств и организаций всех видов и форм собственности по состоянию на 2019 год составляет $90,3 \%$ и $\quad 81,1 \%$ соответственно.

На цифровом рынке Республики Казахстан развитие и расширение услуг по доступу к глобальной сети сопровождалось появлением спектра услуг, связанных с производством и продажей программного обеспечения.

В области формирования предложения программного обеспечения максимальные объемы продаж приходятся на следующие категории: услуги по изданию готового программного обеспечения для инструментов и языков программирования - 35\%; услуги по изданию готового прикладного программного обеспечения - 27\%; услуги по предоставлению лицензий на право использования программного обеспечения $14 \%$ (рисунок 5).
На цифровом рынке Республики Казахстан получают развитие такие дополнительные услуги, как услуги цифровой связи; услуги по компьютерному программированию, консалтингу; услуги по размещению и переработке данных; услуги по разработке веб-порталов; ремонт компьютеров и цифрового коммуникационного оборудования.

Факторами развития данных услуг выступают как рыночная активность хозяйствующих субъектов, так и государственная политика по развитию цифровизации экономики, в том числе инвестиции в цифровую связь, в подготовку кадров. 


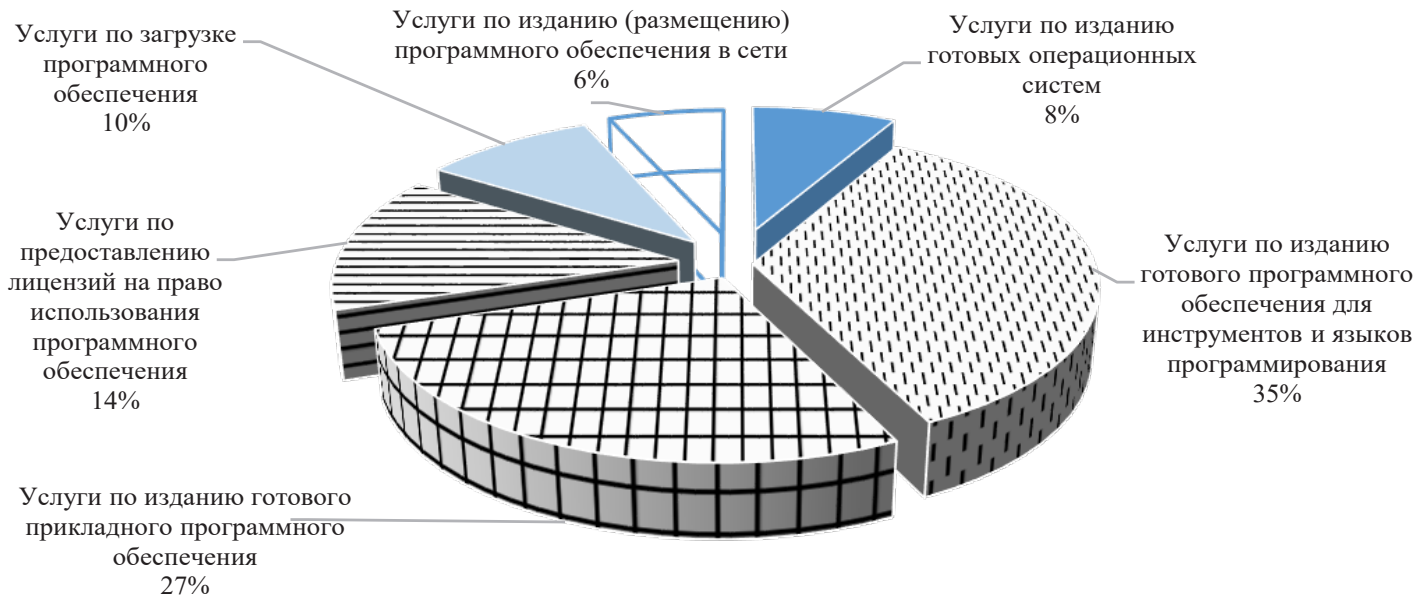

Рисунок 5 - Структура производимого программного обеспечения в Республике Казахстан, 2019 год

Figure 5 - Structure of produced software in the Republic of Kazakhstan, 2019

Примечание - Источник [16].

Представленный спектр услуг позволяет казахстанским организациям, субъектам крупного, малого и среднего бизнеса осваивать технологии построения и проектирования собственных интернет-ресурсов. Удельный вес организаций, имеющих интернет-ресурсы, характеризуется низким показателем - 6,3\% (таблица 7).
В системе деятельности казахстанских организаций имеется положительная динамика внедрения и освоения технологий интранет и экстранет. Удельный вес казахстанских организаций, имеющих данные технологии, по состоянию на 2017 год, составил $31,6 \%$ и $3,2 \%$ соответственно (таблица 8 ).

Таблица 7 - Динамика организаций, имеющих Интернет-ресурсы (интернет-сайты)

Table 7 - Dynamics of organizations with Internet resources (Internet sites)

\begin{tabular}{|l|c|c|c|c|c|}
\hline \multicolumn{1}{|c|}{ Показатель } & \multicolumn{5}{|c|}{ Год } \\
\cline { 2 - 6 } & 2015 & 2016 & 2017 & 2018 & 2019 \\
\hline $\begin{array}{l}\text { Количество организаций, имеющих интернет- } \\
\text { ресурсы }\end{array}$ & 25250 & 21007 & 25950 & 30628 & 25913 \\
\hline Количество организаций, ед. & 338900 & 353800 & 360300 & 383900 & 412700 \\
\hline $\begin{array}{l}\text { Удельный вес организаций, имеющих интернет- } \\
\text { ресурсы, \% }\end{array}$ & 7,5 & 5,9 & 7,2 & 8,0 & 6,3 \\
\hline
\end{tabular}

Примечание - Источник [16].

Таблица 8 - Динамика удельного веса организаций, имеющих доступ к интернет и локальным корпоративным и межкорпоративным ресурсам, \%

Table 8 - Dynamics of the share of organizations with access to the Internet and local corporate and intercorporate resources, \%

\begin{tabular}{|l|c|c|c|c|c|}
\hline \multirow{2}{*}{ Показатель } & \multicolumn{5}{|c|}{ Год } \\
\cline { 2 - 6 } & 2015 & 2016 & 2017 & 2018 & 2019 \\
\hline Удельный вес организаций, имеющих интранет & 18,8 & 27,8 & 31,6 & 31,6 & 31,6 \\
\hline Удельный вес организаций, имеющих экстранет & 1,5 & 3,7 & 3,2 & 3,2 & 3,2 \\
\hline
\end{tabular}

Примечание - Источник [15]. 
В Республике Казахстан на этапе становления и развития находится интернеткоммерция. Об этом свидетельствует степень использования интернета по таким целевым потребительским направлениям, как покупка товаров и услуг, продажа товаров и услуг. Данные показатели составляют 15,6\% и 12,5\% соответственно (таблица 9).
В рамках интернет-коммерции со стороны казахстанских потребителей, максимальный удельный вес интернет-покупок сосредоточен на казахстанских компаниях. Данный показатель составляет - 77\%. На втором месте находятся интернет-покупки товаров и услуг у компаний СНГ. Данный показатель составляет - 30,4\%. Удельный вес интернет-покупок, приходящийся на страны ЕАЭС и страны дальнего зарубежья, составляет $12,1 \%$ и $13,3 \%$ соответственно (рисунок 6).

Таблица 9 - Степень использования интернета по целевым потребительским направлениям

Table 9 - The degree of Internet use by target consumer areas

\begin{tabular}{|l|c|}
\hline \multicolumn{1}{|c|}{ Направление использования интернета } & $\begin{array}{c}\text { Степень использования интернета, } \\
\%\end{array}$ \\
\hline Получение информации о товарах и услугах & 37,1 \\
\hline $\begin{array}{l}\text { Поиск информации, связанной со здравоохранением, или услугами в } \\
\text { области здравоохранения }\end{array}$ & 16,0 \\
\hline Размещение информации, мгновенный обмен сообщениями & 75,7 \\
\hline Скачивание программного обеспечения & 11,8 \\
\hline Скачивание фильмов, изображения, музыки & 63,6 \\
\hline Чтение онлайн газет, журналов & 12,7 \\
\hline Образование и обучение & 14,7 \\
\hline Услуги электронного правительства & 30,4 \\
\hline Покупка товаров и услуг & 15,6 \\
\hline Продажа товаров и услуг & 12,5 \\
\hline
\end{tabular}

Примечание - Источник [16].

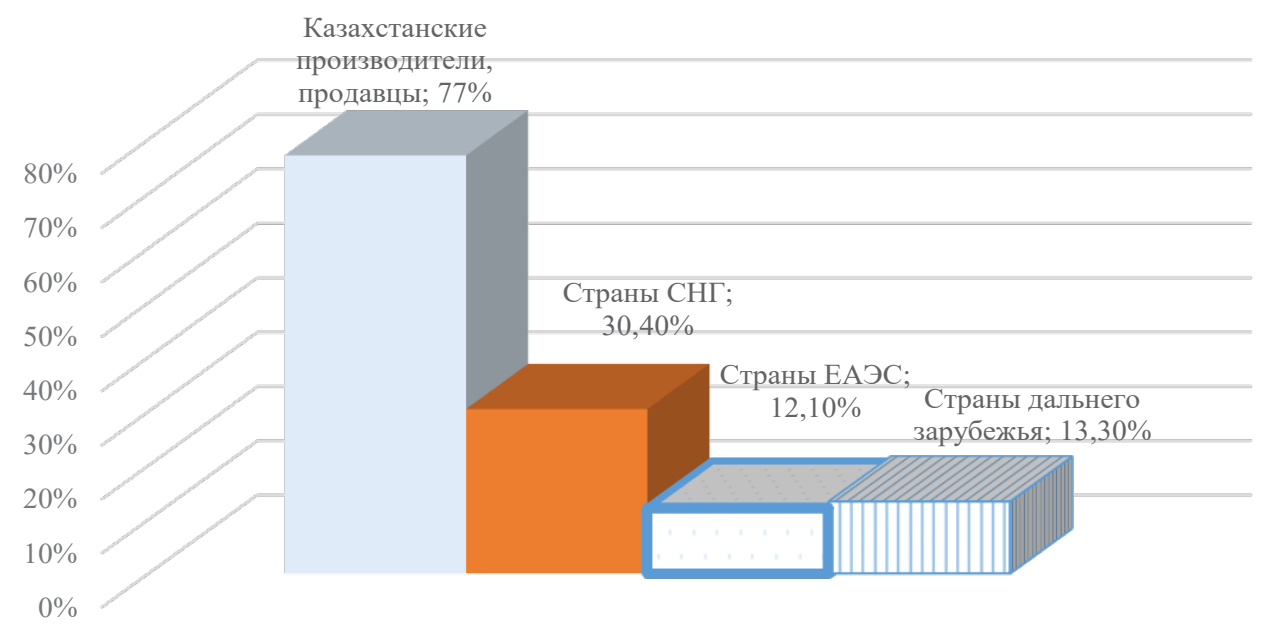

Рисунок 6 - Структурирование интернет-покупок по степени приобретения товаров у казахстанских и зарубежных производителей, продавцов

Figure 6 - Structuring of online purchases by the degree of purchase of goods from Kazakhstani and foreign manufacturers, sellers

Примечание - Источник [16].

В целях рыночной институциональной координации систем и механизмов электронной коммерции в Республике Казахстан в 2019 году была образована Ассоциация «Цифровой
Казахстан», в которую вошли крупнейшие торговые площадки. Миссия ассоциации сосредоточена на развитие в стране сильного рынка электронной коммерции и торговли [20]. 


\section{INNOVATION, INNOVATION AND TECHNOLOGICAL DEVELOPMENT, DIGITALIZATION}

Построение и развитие цифровой экономики Республики Казахстан сопровождается динамическим ростом субъектов цифрового бизнеса и предпринимательства. С 2015 по 2019 годы количество субъектов цифровой экономики выросло с 7715 по 10958 единиц. Максимальный удельный вес занимают малые предприятия (таблица 10).

Начиная с 2017 года, построение цифровой экономики осуществляется с участием государства. В Республике Казахстан принята
Государственная программа «Цифровой Казахстан» на 2018 - 2022 годы, которая предполагает интенсификацию цифровизации особо значимых отраслей промышленности, рост производительности труда, создание умных заводов и фабрик, развитие интернеткоммерции.

Становление и развитие цифровой экономики Республики Казахстан позволило сформировать необходимый базовый спектр услуг, характерный для современного цифрового рынка (таблица 11).

Таблица 10 - Динамика предприятий, функционирующих в отраслях цифровой экономики, ед.

Table 10 - Dynamics of enterprises operating in the sectors of the digital economy, units

\begin{tabular}{|l|c|c|c|c|c|}
\hline \multicolumn{2}{|c|}{ Показатель } & \multicolumn{5}{c|}{ Год } \\
\cline { 2 - 7 } & 2015 & 2016 & 2017 & 2018 & 2019 \\
\hline Крупные предприятия & 73 & 65 & 59 & 42 & 51 \\
\hline Средние предприятия & 96 & 92 & 87 & 89 & 82 \\
\hline Малые предприятия & 7546 & 8349 & 9188 & 10061 & 10825 \\
\hline Итого & 7715 & 8506 & 9334 & 10192 & 10958 \\
\hline
\end{tabular}

Примечание - Источник [15].

Таблица 11 - Динамика оказания услуг на цифровом рынке Республики Казахстан, млн. тенге Table 11 - Dynamics of the provision of services in the digital market of the Republic of Kazakhstan, million tenge

\begin{tabular}{|c|c|c|c|c|c|c|}
\hline \multirow[t]{2}{*}{ Показатель } & \multicolumn{5}{|c|}{ Год } & \multirow{2}{*}{$\begin{array}{c}\text { Темп } \\
\text { роста, } \\
\%\end{array}$} \\
\hline & 2015 & 2016 & 2017 & 2018 & 2019 & \\
\hline $\begin{array}{l}\text { Производство компьютеров и } \\
\text { периферийного оборудования }\end{array}$ & 4327,6 & 3210,9 & 2807,3 & 3638,3 & 5537,1 & 127,9 \\
\hline $\begin{array}{l}\text { Производство электронных } \\
\text { элементов и компьютерных } \\
\text { системных плат }\end{array}$ & 2226,2 & 159,8 & 124,7 & 11,3 & 426,9 & 19,2 \\
\hline $\begin{array}{l}\text { Услуги предоставления доступа } \\
\text { в интернет }\end{array}$ & 190437,5 & 206418,7 & 228686,1 & 243322,7 & 282270,8 & 148,2 \\
\hline $\begin{array}{l}\text { Выпуск программного } \\
\text { обеспечения }\end{array}$ & 995,2 & 1175,8 & 2864,1 & 2422,5 & 1730,5 & 173,9 \\
\hline Услуги цифровой связи & 702148,0 & 722217,4 & 752332,0 & 782459,1 & 854566,4 & 121,7 \\
\hline $\begin{array}{l}\text { Компьютерное } \\
\text { программирование, консалтинг }\end{array}$ & 117383,0 & 141501,9 & 183895,4 & 209057,1 & 277711,9 & 236,6 \\
\hline $\begin{array}{l}\text { Услуги по размещению } \\
\text { и переработке данных, } \\
\text { размещение веб-порталов }\end{array}$ & 45021,5 & 62426,7 & 79449,7 & 102201,8 & 139263,2 & 309,3 \\
\hline $\begin{array}{l}\text { Ремонт компьютеров и } \\
\text { цифрового коммуникационного } \\
\text { оборудования }\end{array}$ & 17367,6 & 18754,8 & 19230,2 & 22682,1 & 31598,1 & 181,9 \\
\hline Итого & 1079906,6 & 1155866,0 & 1269389,5 & 1365794,9 & 1593104,9 & 147,5 \\
\hline
\end{tabular}

Примечание - Источник [15].

Формирование базового спектра услуг, характерного для построения и развития цифровой экономики, создали все необходимые основы для ее интеграции в традиционную (классическую) экономику, при этом для большинства предприятий, фирм, компаний целевым ориентиром стали цифровизация бизнес-процессов, построение систем, механизмов электронной коммерции. 
ИННОВАЦИИ, ИННОВАЦИОННО-ТЕХНОЛОГИЧЕСКОЕ РАЗВИТИЕ, ЦИФРОВИЗАЦИЯ

В цифровом бизнесе и предпринимательстве наблюдается положительная динамика эффективности производственнохозяйственной деятельности. Рост рен- табельности в рассматриваемом периоде вырос с 7,6\% до $18 \%$. При этом значительно преобладает удельный вес прибыльных предприятий (таблица 12).

Таблица 12 - Показатели эффективности функционирования субъектов цифровой экономики

Table 12 - Indicators of the effectiveness of the functioning of the subjects of the digital economy

\begin{tabular}{|c|c|c|c|c|c|}
\hline \multirow{2}{*}{ Показатель } & \multicolumn{5}{|c|}{ Год } \\
\hline & 2015 & 2016 & 2017 & 2018 & 2019 \\
\hline $\begin{array}{l}\text { Валовый внутренний продукт, } \\
\text { млн. тенге }\end{array}$ & 40884133,6 & 46971150,0 & 54378857,8 & 61819536,4 & $\begin{array}{c}69532 \\
626,5 \\
\end{array}$ \\
\hline $\begin{array}{l}\text { Общий объем услуг на цифровом } \\
\text { рынке, млн. тенге }\end{array}$ & 1079906,6 & 1155866,0 & 1269389,5 & 1365794,9 & 1593104,9 \\
\hline $\begin{array}{l}\text { Вклад цифровой экономики в } \\
\text { ВВП, \% }\end{array}$ & 2,64 & 2,46 & 2,33 & 2,21 & 2,29 \\
\hline $\begin{array}{l}\text { Средняя рентабельность } \\
\text { предприятий, функционирующих } \\
\text { в отраслях цифровой экономики, } \\
\%\end{array}$ & 7,6 & 8,3 & 10,0 & 18,2 & 18,0 \\
\hline $\begin{array}{l}\text { Удельный вес убыточных } \\
\text { предприятий, \% }\end{array}$ & 26,6 & 29,0 & 28,7 & 23,0 & 23,3 \\
\hline $\begin{array}{l}\text { Удельный вес прибыльных } \\
\text { предприятий, \% }\end{array}$ & 73,4 & 71,0 & 71,3 & 76,9 & 76,7 \\
\hline
\end{tabular}

Примечание - Источник [16, 21].

Несмотря на динамичное развитие цифровой экономики Казахстана, ее общий суммарный вклад в экономический рост остается незначительным и имеет цикличность. Объемы производства в отраслях цифровой экономики в общем ВВП страны с 2015 по 2019 годы варьировали в пределах от $2,64 \%$ до 2,29\%. Данная тенденция с учетом зарубежного опыта показывает, что в цифровой экономике Казахстана имеются значительные резервы для ее вклада в экономический рост.

Полученные результаты позволяют сделать вывод, что эволюция экономических и организационных основ цифровой экономики Республики Казахстан сопряжена с определенными проблемами, которые являются неизбежными в ходе трансформационных преобразований. В области анализа экономических основ формирования цифровой экономики были выявлены следующие проблемы:

- недостаточно интенсивные тенденции формирования спроса и предложения на цифровом рынке;

- значительное влияние инфляционных процессов на цикличность спроса и предложения на компьютерную технику;
- недостаточные резервы инвестиционных возможностей в расширение парка компьютерной техники организаций, предприятий, фирм, компаний;

- высокий уровень зависимости цифровой экономики от импорта компьютерного оборудования и комплектующих.

В области организационных основ построения цифровой экономики актуально обозначить следующие проблемы:

- значительные резервы построение корпоративных основ цифровизации экономики (невысокий уровень обеспеченности внутренними цифровыми интернет-коммуникациями казахстанских предприятий);

- значительные резервы развития производственных мощностей по производству компьютеров и цифровой электроники на территории страны, в том числе за счет эффективных механизмов трансферта технологий.

\section{Заключение}

В комплексе поставленная цель исследования в настоящей статье достигнута. Проведенное исследование показало, что в Республике Казахстан сформирован прочный фундамент для цифровизации всей экономической системы, а также заложены основы построения и наращивания рынка 
цифровой продукции и технологий, создания и развития бизнес-предпринимательства во всех отраслях цифровой экономики.

Для решения проблем цифровизации экономической системы, по нашему мнению, может быть выдвинута гипотеза о необходимости формирования институциональных основ построения цифровой экономики, ориентированных на реализацию инфраструктурного развития процессов цифровизации на макро- и микроуровнях.

Институциональные основы построения цифровой экономики требуют решения следующих задач:

- необходимо разработать специальные индикативные программы по инфраструктурному цифровому развитию предприятий, фирм, компаний. Основной приоритет при этом должен быть сосредоточен на сектор малого и среднего бизнеса;

- на макроэкономическом уровне необходима разработка стратегии привлечения и финансирования инвестиций в расширение корпоративного парка компьютерной техники;

- на микроэкономических уровнях должны быть разработаны экономические механизмы развития цифровой экономики в системе функционирования малого и среднего бизнеса.

Применительно к макроэкономическому уровню должны быть:

- разработаны экономические сценарии построения цифровой экономики в Республике Казахстан с учетом отраслевой специфики;

- разработаны экономические механизмы устойчивого развития цифровой экономики на стратегический и долгосрочный периоды.

Выше представленные приоритеты могут быть реализованы в практической деятельности в рамках функционирования созданных в регионах Республики Казахстан Управлениями цифровых технологий, a на макроэкономическом уровне в рамках деятельности Министерства цифрового развития, инноваций и аэрокосмической промышленности.

В стратегической перспективе поэтапное наращивание тенденций развития цифровой экономики должно сопровождаться ее тесной интеграцией с инновационной экономикой, ориентированной на производство продукции с высокой добавленной стоимостью в обрабатывающей, в том числе на принципе «интернет-вещей». Особая роль при развитии цифровой экономики должна быть уделена вопросам государственной поддержки цифровизации отраслей и секторов экономики на региональных уровнях. В рамках государственной поддержки цифровой экономики Казахстана основной приоритет должен быть сосредоточен на создание прочного фундамента электронной цифровой промышленности и постепенному уходу от импорта компьютерной техники. Данные вопросы могут быть решены в предстоящем стратегическом и долгосрочном периодах.

\section{Список использованных источников}

1 Dneprov, M.Yu., Mihajlyuk, O.V. (2019) Cifrovaya ekonomika kak novaya ekonomicheskaya kategoriya. Voprosy innovacionnoj ekonomiki, 4, 12791294. https://doi.org/10.18334/vinec.9.4.41249

2 Negroponte, N. (1996) Being Digital. Knopf. Paperback edition, $120 \mathrm{p}$.

3 Cifrovaya ekonomika: kak specialisty ponimayut etot termin. [Elektronnyj resurs]. URL: https://ria.ru/20170616/1496663946.html

(Data obrashcheniya: 06.08.2021)

4 Kaluzhskij, M. L. (2014) Marketingovye seti v elektronnoj kommercii: institucionalnyj podhod. Monografiya, M.: Berlin: Direkt-Media, 402 s.

5 Kelly, K. (1998) New Rules for the New Economy: 10 radical strategies for a connected world. New York: Viking, $224 \mathrm{p}$.

6 Gasanov, G.A., Gasanov, T.A. (2017) Cifrovaya ekonomika kak novoe napravlenie ekonomicheskoj teorii. Regionalnye problemy preobrazovaniya ekonomiki, 6, 4-10.

7 Keshelava, A.V., Budanov, V.G., Rumyancev, V.YU. (2017) Vvedenie v «Cifrovuyu» ekonomiku, VNIIGeosistem, $28 \mathrm{~s}$.

8 Baranov, D.N. (2018) Sushchnost i soderzhanie kategorii «cifrovaya ekonomika». Vestnik Moskovskogo universiteta imeni S. YU. Vitte. Seriya 1. Ekonomika i upravlenie, 2 (25), 15-23. https://doi. org/10.21777/2587-554X-2018-2-15-23

9 Litvinenko, V. S. (2020) Digital Economy as a Factor in the Technological Development of the Mineral Sector. Nat Resour Res, 29, 1521-1541. https://doi. org/10.1007/s11053-019-09568-4

10 Nosova, S.S., Makar, S.V., Gerasimenko, T.I., Medvedeva, O.E., Abdulov, R.E. (2020) Transformation of business models in the mode of the Russian economy digitalization. Revista ESPACIOS, 39 (24), 27. http:// revistaespacios.com/a20v41n12/20411222.html

11 Verhoef, P.C., Broekhuizen, T., Bart, Ya., Bhattacharya, A., Dong, J.Q., Fabian, N., Haenleinc, M. (2021) Digital transformation: A multidisciplinary reflection and research agenda. Journal of Business Research, 122, 889-901. https://doi.org/10.1016/j. jbusres.2019.09.022

12 Ertz, M., Boily, E. (2019) The rise of the digital economy: Thoughts on blockchain technology and cryptocurrencies for the collaborative economy, International Journal of Innovation Studies, 3(4), 8493. https://doi.org/10.1016/j.ijis.2019.12.002 
13 Bejsembaj, E., Titkov, A.A., Ibraimova, S.ZH., Zhappasova, R.E. (2019) Mirovoj opyt postroeniya i funkcionirovaniya cifrovoj ekonomiki, Vestnik nacionalnoj inzhenernoj akademii Respubliki Kazahstan, 4(74), 95-101.

14 Nureev, R.M., Karapaev, O.V. (2019) Tri etapa stanovleniya cifrovoj ekonomiki, Voprosy regulirovaniya ekonomiki, 2, 6-27 https://doi. org/10.17835/2078-5429.2019.10.2.006-027

15 Karpovich, O.G., Karipov, B.N., Nogmova, A.Sh. (2020). Razvitie sifrovoi ekonomiki Kazahstana, Problemy postsovetskogo prostranstva, 7(4), 485-494. https://doi.org/10.24975/2313-89202020-7-4-485-494
16 Razvitie svyazi i informacionnokommunikacionnyh tekhnologij v Respublike Kazahstan. (2020). Statisticheskij sbornik. Nur-Sultan. 17 Kazahstan v cifrah (2016) Broshyura. Astana. 18 Kazahstan v cifrah (2017) Broshyura. Astana.

19 Kazahstan v cifrah (2020) Broshyura. NurSultan.

20 Associaciya «Cifrovoj Kazahstan» [Elektronnyj resurs] URL: https://dka.kz/mission (Data obrashcheniya: 06.08.2021).

21 Kazahstan v 2019 godu (2020) Statisticheskij ezhegodnik. Nur-Sultan.

\section{Information about the authors}

*Ersultan Beisembai - PhD candidate of the Department of Economics, Toraighyrov University, Republic of Kazakhstan, E-mail: beisembai_ersultan@mail.ru. ORCID ID https://orcid.org/0000-0002-5046-030X.

Alexey A. Titkov - Professor of the Department of Economics, Toraighyrov University, e-mail: $\underline{\text { Alexey-pvl@ }}$ mail.ru. ORCID ID https://orcid.org/0000-0001-9126-2337

Saule I. Zhumagalievna - Professor of the Department of Economics, Kazakh University of Technology and Business, Accounting and Auditing. Republic of Kazakhstan, e-mail: saule ibraimova_kz@mail.ru. ORCID ID https://orcid.org/0000-0001-6506-2446

\section{Авторлар туралы мәліметтер}

*Бейсембай Ерсұлтан - Торайғыров университеті, Қазақстан Республикасы, экономика кафедрасының PhD кандидаты, e-mail: beisembai_ersultan@mail.ru. ORCID ID https://orcid.org/0000-0002-5046-030X

Титков Алексей Анатольевич - Торайғыров университеті, экономика кафедрасының профессоры, e-mail: Alexey-pvl@mail.ru. ORCID ID https://orcid.org/0000-0001-9126-2337

Ибраимова Сәуле Жұмағалиқызы - Қазақ технологиялар және Бизнес университеті, Қазақстан Республикасы, экономика, есеп және аудит кафедрасының профессоры, e-mail: saule ibraimova_kz@,mail.ru. ORCID ID https://orcid.org/0000-0001-6506-2446

\section{Сведения об авторах}

* Бейсембай Ерсултан - докторант PhD кафедры Экономики, университет им. С. Торайгырова, Республика Казахстан, e-mail: beisembai_ersultan@mail.ru ; ORCID ID https://orcid.org/0000-0002-5046-030X

Титков Алексей Анатольевич - профессор кафедры «Экономика», университет им. С. Торайгырова, e-mail: $\underline{\text { Alexey-pvl@mail.ru. ORCID ID https://orcid.org/0000-0001-9126-2337 }}$

Ибраимова Сауле Жумагалиевна - профессор кафедры «Экономика, учет и аудит», Казахский университет технологии и бизнеса, e-mail: saule_ibraimova_kz@,mail.ru. ORCID ID https://orcid.org/0000-00016506-2446 